\title{
Novel imaging techniques, integrated with mineralogical, geochemical and microbiological characterizations to determine the biogeochemical controls on technetium mobility in FRC sediments \\ ER63743-1022748-0009741
}

\author{
Jon R. Lloyd (PI) and Joyce M. McBeth* (PhD student) Williamson Research Centre for Molecular \\ Environmental Science and Department of Earth Sciences, University of Manchester, UK \\ Nick D. Bryan and Francis R. Livens, Centre for Radiochemistry Research and Department of \\ Chemistry, University of Manchester, UK \\ Harbans Sharma and Bev Ellis, Dept. Imaging Science and Biomedical Engineering, University of \\ Manchester, UK \\ Collaborators: Kath Morris and lan T. Burke, University of Leeds
}

${ }^{\star}$ Current addresses: Joyce M. McBeth, Bigelow Laboratory for Ocean Sciences, Maine

\section{Aims, objectives and methodologies of grant}

The objective of this research programme was to take a highly multidisciplinary approach to define the biogeochemical factors that control technetium (Tc) mobility in FRC sediments.

The aim was to use batch and column studies to probe the biogeochemical conditions that control the mobility of Tc at the FRC. Background sediment samples from Area $2(\mathrm{pH} \mathrm{6.5,} \mathrm{low} \mathrm{nitrate,}$ low $\left.{ }^{99} \mathrm{Tc}\right)$ and Area $3\left(\mathrm{pH} 3.5\right.$, high nitrate, relatively high $\left.{ }^{99} \mathrm{Tc}\right)$ of the FRC were selected (http://www.esd.ornl.gov/nabirfrc). For the batch experiments, sediments were mixed with simulated groundwater, modelled on chemical constituents of FRC waters and supplemented with ${ }^{99} \mathrm{Tc}(\mathrm{VII})$, both with and without added electron donor (acetate). The solubility of the Tc was monitored, alongside other biogeochemical markers (nitrate, nitrite, $\mathrm{Fe}(\mathrm{II})$, sulfate, acetate, $\mathrm{pH}$, Eh) as the "microcosms" aged. At key points, the microbial communities were also profiled using both cultivation-dependent and molecular techniques, and results correlated with the geochemical conditions in the sediments. The mineral phases present in the sediments were also characterized, and the solid phase associations of the Tc determined using sequential extraction and synchrotron techniques.

In addition to the batch sediment experiments, where discrete microbial communities with the potential to reduce and precipitate ${ }^{99} \mathrm{Tc}$ will be separated in time, we also developed column 
experiments where biogeochemical processes were spatially separated. Experiments were conducted both with and without amendments proposed to stimulate radionuclide immobilization (e.g. the addition of acetate as an electron donor for metal reduction), and were also planned with and without competing anions at high concentration (e.g. nitrate, with columns containing Area 3 sediments). When the columns had stabilized, as determined by chemical analysis of the effluents, we used a spike of the short-lived gamma emitter ${ }^{99 \mathrm{~m}} \mathrm{Tc}(50-200 \mathrm{MBq}$; half life 6 hours) and its mobility was monitored using a $\gamma$-camera. Incorporation of low concentrations of the longlived ${ }^{99} \mathrm{Tc}$ gave a tracer that can be followed by scintillation counting, should the metastable form of the radionuclide decay to below detection limits before the end of the experiment (complete immobilization or loss of the Tc from the column). After the Tc was reduced and immobilized, or passed through the system, the columns were dismantled carefully in an anaerobic cabinet and the pore water geochemistry and mineralogy of the columns profiled. Microbial community analysis was determined, again using molecular and culture-dependent techniques. Experimental results were also modelled using an established coupled speciation and transport code, to develop a predictive tool for the mobility of Tc in FRC sediments.

From this multidisciplinary approach, we hoped to obtain detailed information on the microorganisms that control the biogeochemical cycling of key elements at the FRC, and we would also be able to determine the key factors that control the mobility of Tc at environmentally relevant concentrations at this site.

\section{Hypotheses}

The following hypotheses were selected as a guide for the research.

Hypothesis 1. Tc(VII) will be reduced and precipitated in FRC sediments under anaerobic conditions in batch experiments (progressive microcosms).

Hypothesis 2. $\mathrm{Tc}(\mathrm{VII})$ reduction and precipitation can be visualized in discrete biogeochemical zones in sediment columns using ${ }^{99 \mathrm{~m}} \mathrm{Tc}$ and a $\gamma$-camera.

Hypothesis 3. Sediment-bound reduced ${ }^{99 \mathrm{~m}} \mathrm{Tc}$ can be solublized by perturbations including oxidation by nitrate, and mobilization visualized in real-time using a $\gamma$-camera.

Hypothesis 4. The mobility of ${ }^{99 m} \mathrm{Tc}$ in the sediment columns can be modelled using a coupled speciation and transport code.

\section{Results}

Hypothesis 1. $\mathrm{Tc}(\mathrm{VII})$ will be reduced and precipitated in FRC sediments under anaerobic conditions in batch experiments (progressive microcosms). 
Batch experiments with Area 2 background sediments from the FRC, and model sediment types from other nuclear storage facilities were used to study the biogeochemical behaviour of technetium under a range of nitrate loadings, under both anoxic and oxidising conditions. With low nitrate conditions efficient removal of $0.5 \mu \mathrm{M} \mathrm{Tc}(\mathrm{VII})$ was seen in anoxic microcosms at the onset of Fe(III)-reducing conditions, and was attributed to reduction of the highly soluble $\mathrm{Tc}(\mathrm{VII})$ by $\mathrm{Fe}$ (II) to a lower valence insoluble form of the radionuclide. Furthermore, molecular and cultivation-dependent analysis confirmed the presence of known $\mathrm{Fe}$ (III)-reducing bacteria (Geothrix and Geobacter species) in these sediments. Extended X-ray Absorption Fine Structure (EXAFS) spectroscopic analysis of analogous microcosm experiments, challenged with higher $(550 \mu \mathrm{M})$ concentrations of $\mathrm{Tc}(\mathrm{VII})$, confirmed the presence of reduced insoluble $\mathrm{Tc}(\mathrm{IV})$ as hydrous $\mathrm{TcO}_{2}$ like phases in the $\mathrm{Fe}(\mathrm{II})$-bearing $\mathrm{FRC}$ sediments and in anaologous materials representative of other nuclear sites.

Low (milli molar) concentrations of nitrate had little impact on $\mathrm{Fe}(\mathrm{III}) / \mathrm{Tc}(\mathrm{VII})$ reduction, and in some cases even enhanced Tc(VII) immobilization, presumably by providing nitrogen, a key limiting nutrient in the sediments. High $(100 \mathrm{mM})$ concentrations of added nitrate, however, completely inhibited metal $(\mathrm{Fe}(\mathrm{III}) \mathrm{Tc}(\mathrm{VII}))$ reduction over the timescale of the experiments. Similar observations were made with low pH / high nitrate sediments from Area 3 (near FW 009), illustrating the dramatic impact of nitrate as a competing electron acceptor such that metal reduction and Tc immobilization was inhibited. Very long incubation times were needed for $\mathrm{Tc}(\mathrm{VII})$ bioremediation in these sediments, taking place only after complete denitrification.

Finally, working towards hypothesis 3 below, reoxidation experiments of pre-reduced microcosms which had been reductively labelled with $0.5 \mu \mathrm{M}{ }^{99} \mathrm{Tc}$ showed very limited (<3\%) remobilization of reduced ${ }^{99} \mathrm{Tc}$ with $100 \mathrm{mM}$ nitrate but significant ( $\left.80 \%\right)$ remobilization of ${ }^{99} \mathrm{Tc}$ under air reoxidation conditions. $\mathrm{Fe}(\mathrm{II})$ oxidation was, however, significant in all oxidation treatments. EXAFS analyses of Fe(II)-bearing sediments challenged with higher (550 $\mu \mathrm{M})$ concentrations of $\mathrm{Tc}(\mathrm{VII})$ and then reoxidized with $100 \mathrm{mM}$ nitrate showed the systems contained both $\mathrm{Tc}(\mathrm{IV})$ and $\mathrm{Tc}(\mathrm{VII})$ immobile phases. These results suggest that under anaerobic oxidation conditions, Tc(IV) will not remobilize rapidly, even in the presence of high concentrations of nitrate. This obviously has implications for the biogeochemical cycling of technetium in contaminated environments, including those where bioreduction has been stimulated to minimize transport of the radionuclide.

The results from this comprehensive FRC study were published in the Geomicrobiology Journal (McBeth et al. 2007) 
Hypothesis 2. $\mathrm{Tc}(\mathrm{VII})$ reduction and precipitation can be visualized in discrete biogeochemical zones in sediment columns using 99mTc and a gamma-camera.

Initial proof of concept microcosms containing Fe(II)-bearing, microbially-reduced FRC sediments were spiked with $99 \mathrm{mTc}$ and imaged using a gamma-camera. In comparison with oxic controls, $99 \mathrm{mTc}$ was significantly partitioned in the solid phase in Fe(III)-reducing sediments in batch experiments.

Subsequent column studies with $\gamma$-camera imaging of radiotracer ${ }^{99 m} \mathrm{Tc}(\mathrm{VII})$ was used successfully to assess the impact of biostimulation of metal-reducing bacteria on the mobility of technetium in FRC sediments. Additions of electron donor (acetate) were used to construct a redox gradient in sediment columns, from oxic to $\mathrm{Fe}$ (III)-reducing conditions with increasing depth. When ${ }^{99 \mathrm{~m}} \mathrm{Tc}$ was pumped through the columns, real-time $\gamma$-camera imaging in combination with geochemical analyses showed that the technetium was localised in regions of biogenic $\mathrm{Fe}(\mathrm{II})$. In parallel experiments electron microscopy with EDX mapping confirmed that sediment bound Tc was co-located with iron, while XAS confirmed reduction of $\mathrm{Tc}(\mathrm{VII})$ to insoluble $\mathrm{Tc}(\mathrm{IV})$ as hydrous $\mathrm{TcO}_{2}$ like phases. Molecular analyses of the microbial communities in experiments identified a direct link between the accumulation of biogenic $\mathrm{Fe}(\mathrm{II})$ and $\mathrm{Tc}(\mathrm{VII})$ reductive precipitation, with $\mathrm{Fe}$ (III)-reducing bacteria also more abundant in technetium immobilization zones. A manuscript describing this work is currently "in revision" for Environmental Science and Technology.

Hypothesis 3. Sediment-bound reduced $99 \mathrm{mTc}$ can be solublized by perturbations including oxidation coupled to biological nitrate reduction, and mobilization visualized in real-time using a gamma-camera.

Significant progress was made focusing on the impact of nitrate on the biogeochemical behaviour of technetium (see experiments described above under hypothesis 1 and published alongside progressive "reducing" microcosm experiments in McBeth et al, 2007). Additions of $100 \mathrm{mM}$ nitrate to FRC sediment microcosms, which could potentially compete for electrons during metal reduction, inhibited the reduction of both $\mathrm{Fe}(\mathrm{III})$ and $\mathrm{Tc}(\mathrm{VII})$ completely. Experiments have also addressed the impact of high nitrate concentrations on $\mathrm{Fe}(\mathrm{II})$ and $\mathrm{Tc}(\mathrm{IV})$ in pre-reduced sediments, showing no significant resolubilization of Tc with the addition of $25 \mathrm{mM}$ nitrate. A parallel set of experiments addressing the impact of aerobic conditions on the stability/solubility of $\mathrm{Fe}(\mathrm{II})$ and Tc(IV), found $80 \%$ resolubilization of the Tc. 
As iron minerals were shown to impact on the redox behaviour and mobility of $\mathrm{Tc}(\mathrm{VII})$ in the batch and column studies, we investigated further interactions with several model iron minerals with the potential to control the biogeochemical behaviour of technetium. Pertechnetate $\left(\mathrm{TcO}_{4}{ }^{-}\right)$was added to samples of biogenic and abiotically produced Fe(II) phases (magnetite, vivianite, siderite, and a poorly crystalline Fe(II) mineral - from a microbial growth medium). The technetium was reduced and immobilized on the $\mathrm{Fe}$ (II) phases. Upon exposure to the atmosphere, Tc was not reoxidized or remobilized. Samples of minerals inoculated with a culture of nitrate-reduction coupled Fe(II) oxidizers did not reoxidize or remobilize Tc and seemed to be unable to couple reoxidation of $\mathrm{Fe}(\mathrm{II})$ in bio-precipitated vivianite, magnetite, or siderite to $\mathrm{NO}_{3}{ }^{-}$ reduction, but were able to reoxidize an "Fe(II)-gel" phase.

Due to time constraints, examination of reoxidation behaviour in column experiments was not conducted, however reoxidation experiments using Area 2 sediments from parallel Area 2 sediment incubations did not show any change in the valence of ${ }^{99} \mathrm{Tc}$ in the reduced vs reoxidized sediments.

The behaviour of technetium in sediment-based microcosms during reoxidation regimes has been the focus of several published manuscripts (see below), with an additional manuscript in an advanced level of preparation, discussing the interactions of Tc with model Fe mineral phases under reoxidation regimes.

Hypothesis 4 The mobility of $99 \mathrm{mTc}$ in the sediment columns can be modelled using a coupled speciation and transport code.

Modelling of Tc sorption in the sediment columns using a 1-D coupled chemical advection/dispersion transport model indicated that Tc sorbs irreversibly (over the timescale of a $14.5 \mathrm{hr}$ experiment) to the Fe(III)-reducing sections of sediment columns. This was included in our Environmental Science and Technology paper, currently in revision.

\section{Conclusions}

A multi disciplinary approach was used successfully to monitor the biogeochemical behaviour of technetium in FRC sediments and other model sediment systems under reducing and oxidising conditions. Key observations were a link between the radionuclide and $\mathrm{Fe}$ (II)-bearing mineral phases at low and ultra low Tc concentrations, and a recalcitrance to remobilization during reoxidation. 


\section{Training graduate student destination}

Dr Joyce McBeth graduated in 2007 and is now a postdoctoral scientist at Bigelow Laboratory for Ocean Sciences, West Boothbay Harbor, ME. Dr Gavin Lear offered some molecular ecology support during this project, and is currently a postdoctoral scientist at the University of Auckland.

Thesis produced: McBeth, J.M. (2008) Biogeochemical Redox Cycling of Technetium. PhD Thesis, The University of Manchester School of Earth, Atmospheric, and Environmental Sciences. 254pp.

\section{Publications}

Morris, K., F.R. Livens, J.M. Charnock, I.T. Burke, J. M. McBeth, J. D. C. Begg, C. Boothman and J.R. Lloyd (2008) An X-ray absorption study of the fate of technetium in reduced and reoxidised sediments and mineral phases. Applied Geochemistry. 23 603-617

Wilkins, M.J., Livens, F.R., Vaughan, D.J., Beadle, I. and Lloyd, J.R. (2007) The Influence of Microbial Redox Cycling on Radionuclide Mobility in the Subsurface at a Low-Level Radioactive Waste Storage Site Geobiology 5 293-301

Lloyd, J.R., Beveridge, T.J., Morris, K., Polya,' D.A. and Vaughan, D.J. (2007). Techniques for studying microbial transformations of metals and radionuclides. In Manual of Environmental Microbiology. Amercian Society for Microbiology. Washington DC 1195-1213

Morris, K., F.R. Livens, J. M. Charnock, I.T. Burke, J.M. McBeth, C. Boothman, J.R. Lloyd (2007) Microbially driven transformations of technetium. Nuclear Science 71-81

Renshaw, J.C., J.R. Lloyd and F.R. Livens (2007) Microbial interactions with actinides and longlived fission products. Comptes Rendus Chimie 10 1067-1077

McBeth, J.M., Lear, G., Morris K., Burke" I.T. Livens, F.R. and Lloyd, J.R. (2007). Technetium Reduction and Reoxidation in Aquifer Sediments. Geomicrobiology Journal 24 189-197

Burke I. T., Boothman C., Lloyd J. R., Livens F. R., Charnock, J.M., McBeth, J.M,, Mortimer R.J.G. and Morris K. (2006). Reoxidation behaviour of technetium, iron and sulfur in estuarine sediments. Environmental Science and Technology. 40, 3529-3535. 
Morris, K. and Lloyd, J.R. (2006). Radioactive "stick-in-the-muds". Planet Earth Spring Edition 21-22

Morris, K., F.R. Livens, J. Charnock, I.T. Burke, J.M. McBeth, C. Boothman, J.R. Lloyd. Microbially driven transformations of technetium. Proc. 4th Int Workshop on Actinide XAS, 2006. Sept 18-20th 2006. NEA Publications.

Wilkins, M.W., Livens, F.R., Vaughan, D.J. and Lloyd, J.R. (2006) The impact of Fe(III)-reducing bacteria on uranium mobility Biogeochemistry 78: 125-150

Burke, I.T., Boothman, C., Lloyd, J.R., Livens, F.R., Charnock, J.M., McBeth, J.M., Mortimer, R.J.G. and Morris, K. (2006) Redoxidation behaviour of technetium, iron and sulfur in estuarine sediments. Environmental Science and Technology 403529 - 3535

Zachara, J. and Lloyd, J.R. (2005) "What are the major research needs and approaches for evaluating reoxidation processes" Report for breakout session at DOE NABIR annual PI meeting.

Lloyd JR (2005) Mechanisms and environmental impact of microbial metal reduction. In: Gadd GM, Semple KT and Lappin-Scott HM (eds). Micro-organisms and earth systems - advances in geomicrobiology, Vol 65. Cambridge: Cambridge University Press, pp. 273-302.

Lloyd J.R., Renshaw J.C., May I., Livens F.R., Burke I.T., Mortimer R.J.M. and Morris K. (2005) Biotransformation of actinides: Microbial reduction of actinides and fission products. Journal of Nuclear and Radiochemical Science. 6 (1) 17-20.

Lloyd, J.R. and Renshaw, J.C. Microbial Transformations of Radionuclides: Fundamental Mechanisms and Biogeochemical Implications (2005) in "Biogeochemical Cycles", Vol. 43 of Met. Ions Biol. Syst. M. Dekker, New York. pp. 205-240.

Burke I.T., Boothman C., Lloyd J.R., Mortimer R.J.M., Livens F.R. and Morris K. (2005) Effects of progressive anoxia on the solubility of technetium in sediments. Environmental Science and Technology 39 (11) 4109-4116.

Burke I.T., Mortimer R.J.M., Morris K., Boothman C., Livens F.R. and Lloyd J.R. (2005) How microbial processes in estuarine sediments can control the mobility of the radionuclide, technetium. Royal Society of Chemistry, Environmental Chemistry Group Bulletin (July) 2-4. 
Lloyd, J.R., Anderson, R.T., Macaskie, L.E. (2005) Bioremediation of metals and radionuclides. In "Bioremediation" Ed by R.Atlas and J. Philp. ASM Press Washington pp 293-317.

Lloyd J.R., Lovley, D.R., Macaskie, L.E. (2004) Biotechnological application of metal-reducing microorganisms. Advances in Applied Microbiology, 53: 85-128.

Lloyd JR (2003) Microbial reduction of metals and radionuclides. FEMS Microbiology Reviews. 27: 411-425.

\section{Offered Conference Presentations:}

McBeth, JM, G Lear, C Boothman, K Morris, IT Burke, FR Livens, B Ellis, R Lawson, JR Lloyd. Anoxic cycling of technetium in aquifer sediments - a novel application of gamma camera imaging. Frontiers in Mineral Sciences - Joint Meeting of Mineralogical Association of Canada (MAC), Mineralogical Society (MS), Mineralogical Society of America (MSA), Société Française de Minéralogie et de Cristallographie (SFMC), Cambridge, UK, June 26-28, 2007

McBeth, JM, G Lear, C Boothman, K Morris, IT Burke, FR Livens, B Ellis, R Lawson, JR Lloyd. Technetium biogeochemistry and redox cycling. Research in Progress Meeting. Mineralogical Society (Environmental Mineralogy group), Manchester, UK. 24 April 2007

McBeth, JM, G Lear, C Boothman, K Morris, IT Burke, FR Livens, B Ellis, R Lawson, JR Lloyd. Anoxic Cycling of Technetium in Aquifer Sediments at the DoE Field Research Center. $11^{\text {th }}$ International Symposium on Microbial Ecology (ISME-11), August 20-25, 2006 in Vienna, Austria

McBeth, JM, G Lear, C Boothman, K Morris, IT Burke, FR Livens, B Ellis, R Lawson, JR Lloyd. Biogeochemistry of Technetium: Use of EXAFS and Gamma Camera Imaging to Gain Insight into the Reoxidation Behaviour of a Radioactive Heavy Metal Contaminant. Mineralogical Society (Environmental Mineralogy group) Research in Progress Meeting, April 6, 2006 in London, UK.

McBeth, J.M., Lear, G., Morris, K., Burke, I.T., Livens, F.R., Ellis, B., Lawson, R.S., Lloyd, J.R. Anoxic cycling of technetium in aquifer sediments; a multidisciplinary study. Society for General Microbiology, 157th Meeting. Keele, UK (September 2005) 
Burke I. T., Boothman C., Lloyd J. R., Mortimer R. J. G., Livens F. R. and Morris K. Technetium solubility during the onset of progressive anoxia. Society for General Microbiologists, 157th Meeting, Keele, UK (September 2005)

Morris K., Lloyd J. R., Burke I. T., Boothman C., Livens F. R. and Mortimer, R. J. G. Biogeochemical redox cycling of technetium in estuarine sediments. Society for General Microbiologists, 157th Meeting, Keele, UK (September 2005)

Boothman C., Burke I.T., Morris K. and Lloyd J.R. Anoxic biogeochemical cycling of iron; characterisation of a stable microbial consortium coupling anoxic oxidation of $\mathrm{Fe}$ (II) to nitrate reduction. Society for General Microbiologists, 157th Meeting, Keele, UK (September 2005)

McBeth, J.M., Lear, G., Morris, K., Burke, I.T., Livens, F.R., Ellis, B., Lawson, R.S., Lloyd, J.R. Anoxic cycling of technetium in aquifer sediments; a multidisciplinary study combining geochemical, microbiological and novel imaging techniques. The Joint International Symposia for Subsurface Microbiology (ISSM 2005) and Environmental Biogeochemistry (ISEB XVII). Jackson Hole, WY, USA (August 2005)

Lloyd, J.R., McBeth, J.M., Lear, G., Morris, K., Burke, I.T., Livens, F.R., Ellis, B., Lawson, R.S. Investigation of technetium redox cycling in FRC background sediments using EXAFS and Gamma Camera Imaging. NABIR P.I. Meeting, Warrenton, VA, USA (April 2005)

McBeth, J.M., Lear, G., Morris, K., Burke, I.T., Livens, F.R., Lloyd, J.R. Redox cycling of technetium in aquifer sediments. Mineralogical Society Winter Meeting, Bath, UK (January 2005)

Burke I. T., Boothman C., Lloyd J. R., Livens F. R., Mortimer, R. J. G. and Morris K. Reoxidation and remobilisation of technetium from Tc-radiolabeled sediments. Mineralogical Society Winter Meeting, Bath, UK (January 2005)

Burke I. T., Boothman C., Lloyd J. R., Mortimer R. J. G. and Morris K. Reductive precipitation of TcO4- in estuarine sediments. Mineralogical Society Winter Meeting, Bath, UK (January 2005)

Burke I. T., Boothman C., Lloyd J. R., Livens F. R., Mortimer R. J. G. and Morris K. Technetium remobilisation during the reoxidation of Tc-radiolabeled sediments. VM Goldschmidt Geochemistry, Copenhagen, Denmark (2004) 
Morris K., Burke I. T., Boothman C., Lloyd J. R. and Mortimer R. J. G. Technetium solubility during the onset of progressive anoxia. VM Goldschmidt Geochemistry, Copenhagen, Denmark (2004)

Lloyd, J.R., McBeth, J.M., Livens, F.R., Bryan, N.D.., Ellis, B., Burke, I.T., Morris, K. Biogeochemical controls on technetium mobility in FRC sediments. NABIR P.I. Meeting, USA. (2004)

Burke I. T., Boothman C., Lloyd J. R., Mortimer R. J. G. and Morris K. Biogeochemistry of technetium: progressive anoxia microcosm results. 6th International Symposium on Environmental Geochemistry, Edinburgh, UK (2003)

\section{Invited presentations (Jon Lloyd)}

CoEBio3 Annual Conference, Manchester Interdisciplinary Biocentre (2007)

Cambridge University Surface Science Group (2007)

Cambridge University/Min Soc Techniques in Geomicrobiology Short Course (2007)

ASM Toronto (2007)

EGU (2007)

American Chemical Society, Chicago (2007)

University of Oxford (2007)

Manchester Metropolitan University (2007)

RSC Radiochemistry Group Symposium on Radioactively Contaminated Land, University of Leeds (2006)

University of Kent (2006)

$19^{\text {th }}$ IMA Meeting, Keynote, Kobe, Japan (2006)

International Workshop Low Temp Geochemistry, Hokkaido, Japan (2006)

Environmental Biotechnology, Plenary, Wageningen (2006)

University of Sheffield (2006)

University of Guelph, Canada (2006)

Nexia/Nuclear Decommissioning Authority meeting, Liverpool (2006)

University of Bristol (2006)

University of Birmingham (2006)

ISEB 17/ISSM Wyoming (2005)

ESRF meeting on iron cycling in the environment University of Bayreuth (2005)

SGM Geomicrobiology Main Symposium, University of Keele (2005)

University of Edinburgh, SGM sponsored lecturer (2005) 
University of Bangor (2005)

NW Microbiology, Plenary, (2005)

Symposium on Interactions of Heavy Elements with Microorganisms, Tokai, Japan (2004)

European Meeting for Biotechnologies, Marseille, France (2004)

Biometals, Garmisch Partenkirchen, Germany (2004)

\section{Invited presentations (Francis Livens)}

Nuclear Decommissioning Authority (Jan 2007)

AWE Aldermaston (Feb 2007)

Actinides Summer School, ITU Karlsruhe (June 2007)

CEA Summer School, Marcoule (Aug 2007)

Royal Society of Chemistry "Radiochemistry in Nuclear Waste Disposal", Cumbria (2005);

Royal Society of Chemistry "Materials for Nuclear Waste Management", London (2006);

International Actinides Summer School, ITU Karlsruhe (2005);

6th International School on Physics and Chemistry of Actinides, Oxford (2006)

\section{Grant proposals funded}

CCLRC, Daresbury beamtime award number 44055

CCLRC, Daresbury beamtime award number 46140

(pending: CCLRC, Daresbury beamtime application period 48)

CCLRC, Daresbury beamtime award number 48190

CCLRC Daresbury, beamtime award number 42053.

NERC "The environmental behaviour of redox active radionuclides" (2006-2009) £325,784 